\title{
A Comprehensive Study of Leachate Characteristics from Three Soluos Dumpsites in Igando Area of Lagos State, Nigeria
}

\section{${ }^{1 *}$ Salami L. and ${ }^{2}$ Susu A.A.}

${ }^{1}$ Department of Chemical and Polymer Engineering, Lagos State University, Epe, Lagos State, Nigeria

${ }^{2}$ Department of Chemical Engineering, University of Lagos, Akoka, Lagos State, Nigeria

Article No.: 110118520

Type: Research

DOI:10.15580/GJEMPS.2019.1.110118520

Submitted: 01/11/2018

Accepted: 15/12/2018

Published: 06/01/2019

${ }^{\star}$ Corresponding Author

Salami L.

E-mail: SalamiLukumon@yahoo. com

Keywords: Soluos dumpsites, solid waste, leachates, contaminants, correlation matrices.
Leachate from dumpsites is a threat to soil, vegetation, surface and groundwater within the vicinity of the dumpsites. This work was carried out to comprehensively study the leachates from three Soluos dumpsites with a view of establishing correlation matrix for the leachate parameters in each of the dumpsites. The locations of the dumpsites were identified using Global Positioning System (GPS). Four different leachate samples were taken in each of the dumpsites and all the samples were analysed for thirty four leachate parameters according to the America Public Health Association (APHA). The results of the analysis were used to develop correlation matrices using the in-built Pearson product moment correlation coefficient solver tool in Microsoft Excel version 7. The results of the analysis reveal that some parameters such as biochemical oxygen demand, chemical oxygen demand, copper and chromium exceeded the permissible limits of the regulatory bodies. The correlation matrices showed a strong relationship among the leachate parameters and it was therefore recommended that the current practise of waste mix in the dumpsites should be stopped and the dumpsites leachates should be treated. 


\section{$1.0 \quad$ INTRODUCTION}

Landfill leachate produced from municipal solid waste is generally heavily contaminated and consists of complex wastewater (Mohajeri et al., 2010; Foul et al., 2009 and David et al., 2009). The generation of leachate is a result of percolation of precipitation through open landfill coupled with any disposed liquid wastes, results in the extraction of water soluble compounds and particulate matter of the wastes (Aziz et al., 2007). Leachate is characterised by high concentration of organic matter (biodegradable and non-biodegradable), ammonia, nitrogen, heavy metals and chlorinated organic and inorganic salts (Renou et al., 2008).

The characteristics of leachate are highly variable depending on the waste composition, amount of precipitation, site hydrology, waste compaction, cover design, sampling procedures and interaction of leachate with the environment, landfill design and operation (Kulikowska and Klimium, 2008 and Reinhart and Grosh, 1998). Disposal of solid wastes in major cities of Nigeria in the last few decades has contributed to major environmental public health problems. This has become a source of worry especially in Lagos, the most populous city in Nigeria because of the explosive population growth rate and urbanisation (Adedosu et al., 2013).

Extensive research works on leachates from myriad dumpsites have been reported. Reinhart and Grosh (1998) established that hardly different leachates will have the same quality. Kumar and Alappat (2003) worked on the analysis of leachate contamination potential using leachate pollution index (LPI). Fourteen leachate parameters were used to calculate the LPI. The work showed that the LPI of Okhla landfill in New Delhi in India was very high and proper treatment of leachate from the landfill site was recommended. Alimbat et al. (2006) examined the potential mutagenic effects of raw and simulated leachates from Olusosun municipal solid waste dumpsite. Seventeen leachate parameters were examined. The examination revealed that the municipal solid wastes leachates can induce genotoxicity in rat which pointed to the potential health risk to human population. Ogundiran and Afolabi (2008) assessed the physico-chemical parameters and heavy metal toxicity of leachates from Olusosun municipal solid waste dumpsite in Ojota axis of Lagos State. Thirteen leachate parameters were assessed. The assessment established that leachates from Olusosun dumpsite have the potential to contaminate the neighbouring groundwater. Aderemi et al. (2011) assessed the leachates from Soluos dumpsite using thirteen leachate parameters. The work showed that the leachate from Soluos dumpsite has not affected the natural resources within the vicinity negatively. Afolayan et al. (2012) compared the concentration of physico-chemical, chemical and biological parameters in three samples of leachate from different dumpsites in Soluos community of Igando in Lagos State. Nineteen leachate parameters were compared. The work indicated that most of the leachates parameters reduced in quantity, toxicity and concentration with respect to time and type of landfill either open or closed. Rajkumar et al. (2012) characterised the leachate from Tamil Nadu landfill site in India. Seventeen leachate parameters were characterised. The work revealed that the leachate from the dumpsite can pollute groundwater integrity. Adedose (2013) assessed the heavy metals in leachate samples collected from the vicinity of Olusosun dumpsite in Lagos State. Six leachate parameters were assessed. The assessment revealed the leakage of leachates from Olusosun dumpsite to the surrounding soil which posed a potential danger to the host community.

Olubunmi (2013) studied the variation of leachate characterisation in Soluos1, Soluos 2 and Abule Egba dumpsites in Lagos State. Ten leachate parameters were investigated. The study revealed that the leachate generated during wet season was more mineralised with low concentration of trace metals in all the dumpsites considered in the study. Wijesekara et al. (2014) studied the fate and transport of pollutants through a municipal solid waste landfill leachate from Gohagoda dumpsite in Sri Lanka. Twenty five leachate parameters were considered. The work revealed that leachate from Gohagoda dumpsite in Sri Lanka exceeded the allowable limits of Sri Lankan wastewater discharge standard for most parameters considered.

It is evident from the previous works on leachates that no comprehensive study has been carried out on leachates from the three Soluos dumpsites. Hence the aim of this work is to comprehensively study the leachates from the three dumpsites located in Soluos community in Igando area of Lagos State in order to provide an in-depth characteristics of the leachates with a view of establishing correlation matrix for leachate parameters in each of the dumpsites. The comprehensive study of leachates from the dumpsites presents a proper understanding of the behaviour of dumpsite leachates and provides an insight into differences in leachate characteristics in dumpsites whose locations are in close proximity.

A correlation analysis is a descriptive technique for understanding the statistical relationship between two or more variables or systematic changes in the value of one variable as accompanied by systematic changes in the other. Hence, this statistical explanation can be used to understand the relationship between two variables (Wijesekara et al., 2014).Ogudiran and Afolabi (2008) showed that there was a very high correlation among all leachates parameters considered in their work. Adedosu (2013) revealed that there was a high correlation among the heavy metals in dumpsite leachates which suggested that most of the metals have a common source. A very high correlation among dumpsite leachate parameters have also been revealed in the work of Milke and Huitric (1993) and Wijesekara et al., (2014). Therefore this work will serve as an important tool for Lagos State Government to fashion out remediation strategies for leachates from Soluos 
dumpsites and to plan the waste mix for Lagos State dumpsites.

\subsection{STUDY AREA}

Soluos community is situated at Ikotun/lgando Local Council Development Area of Alimosho Local Government in Lagos State, Nigeria. Three dumpsites are located in the Soluos community known as Soluos 1 (Closed), Soluos 2 and Soluos 3 (open). Soluos 1 covers about 7.8 hectares of land, Soluos 2 covers approximately 3.2 hectares of land, Soluos 3 covers about 5 hectares of land. The Soluos dumpsites are surrounded by commercial and industrial set up as well as clustered human settlement. The dumpsite has witnessed rehabilitation which comprised reclamation of land, construction of accessible road for case tipping, spreading and compaction of waste since inception
(Longe and Balogun, 2010). The wastes in Soluos dumpsites are of different types, ranging from organic to inorganic, hazardous and non-hazardous. The waste stream is made up of domestic, market, commercial, industrial and institutional origins (Longe and Balogun, 2010). Soluos 1 and 2 started operation in 1994 and 1996 respectively while Soluos 3 started operation in 2006. The Soluos dumpsites are non-engineered landfill with a huge heap of waste. Trucks from different parts of Alimosho area of Lagos State collect and bring wastes to these sites and dump them in irregular fashion. The wastes are dumped without separation but the rag pickers who constitute the informal sector rummage through the waste, help in segregating them by collecting the plastic and other valuable items and sell them to the recycling industries. The typical views of Soluos 1, 2 and 3 dumpsites are shown in Figures 1,2 and 3 respectively.

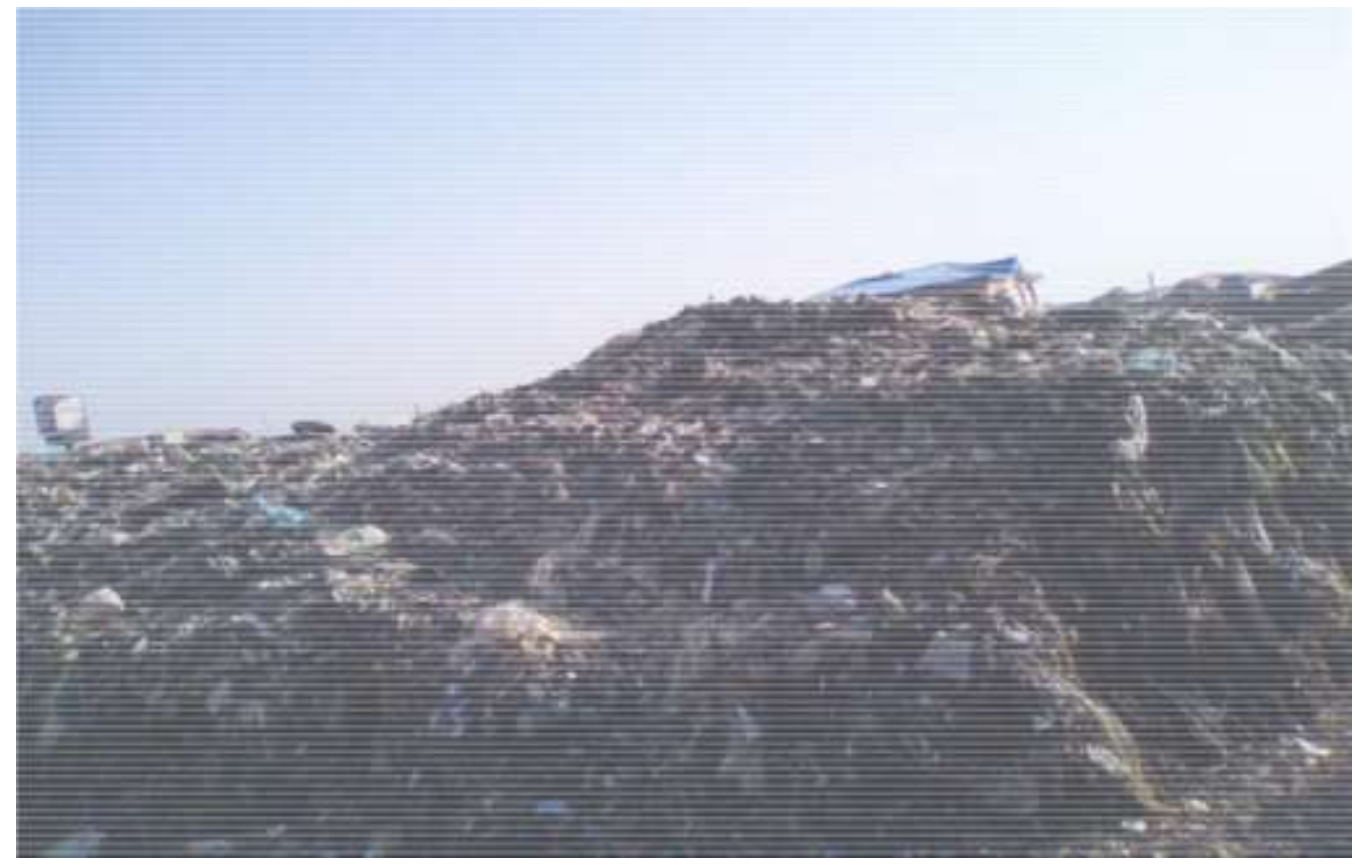

Figure 1: A typical view of Soluos 1 dumpsite in Igando area of Alimosho Local Government of Lagos State, Nigeria

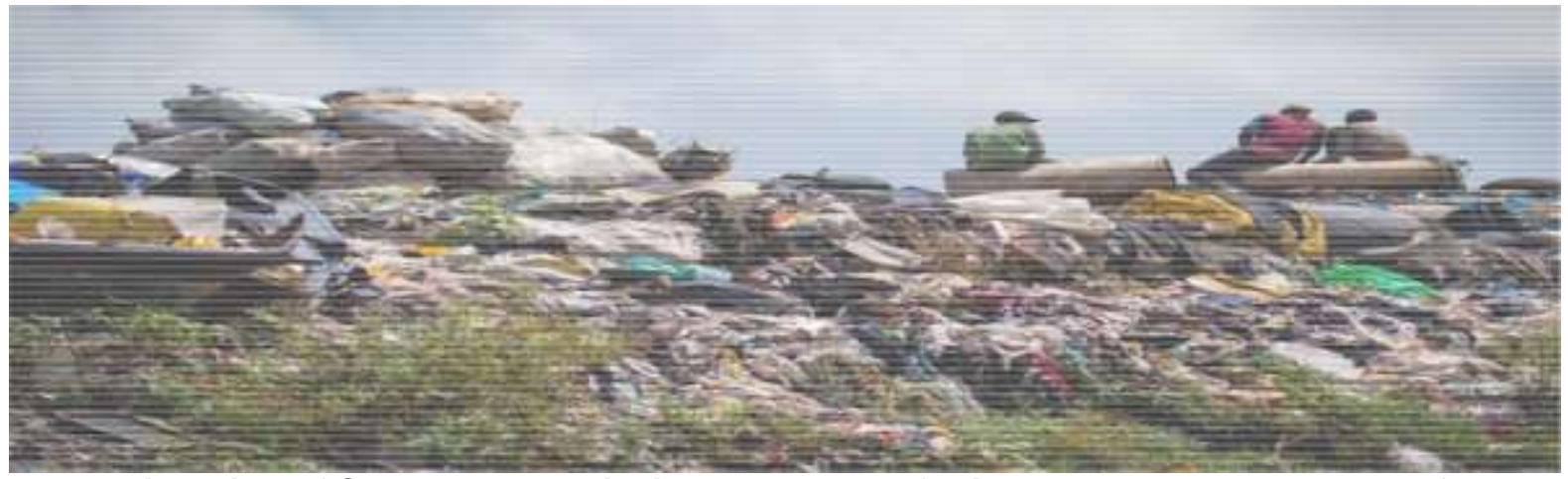

Figure 2: A typical view of Soluos 2 dumpsite in Igando area of Alimosho Local Government of Lagos State, Nigeria. 


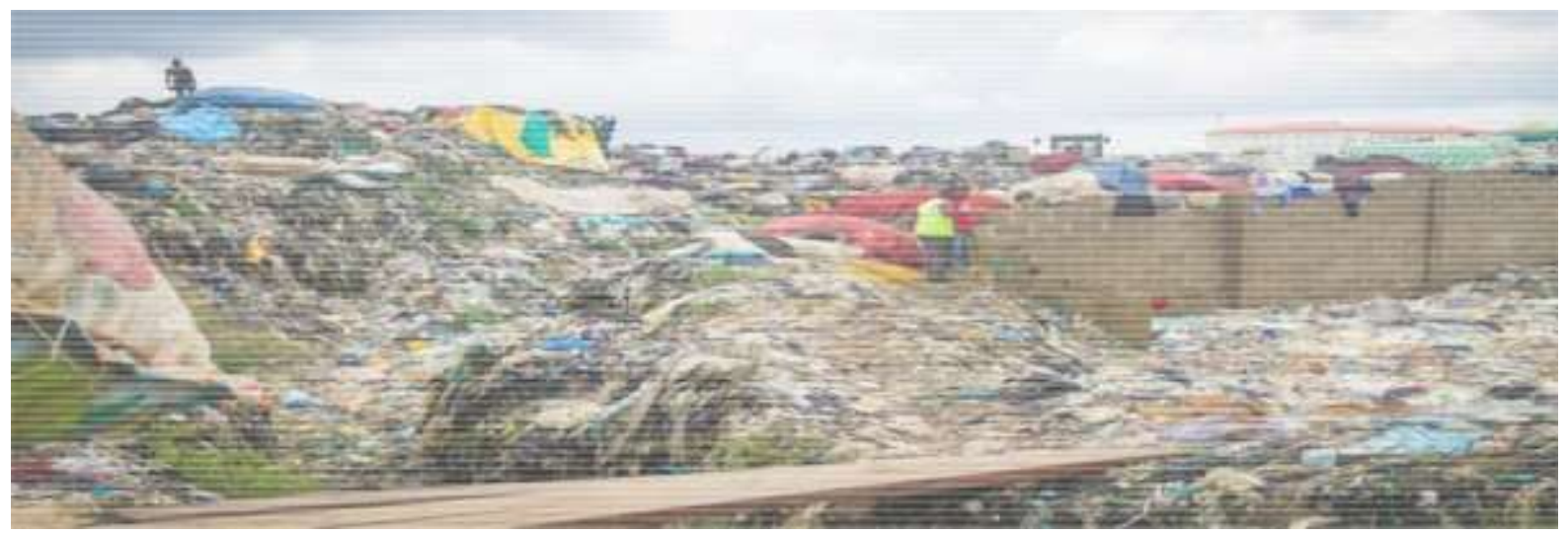

Figure 3: A typical view of Soluos 3 dumpsite in Igando area of Alimosho Local Government of Lagos State, Nigeria.

\subsection{METHODOLOGY}

\subsection{Location of Position of Dumpsites}

The location of the Soluos dumpsites was carried out using Global Positioning System(GPS) in order to identify the dumpsites universally. The pictures depicting these locations are shown in Figure 4 for Soluos 1 and 2 and Figure 5 for Soluos 3 . The corresponding final plans of the project sites that were over laid on the satellite imagery are shown in Figure 6 for Soluos 1 and 2 dumpsites.

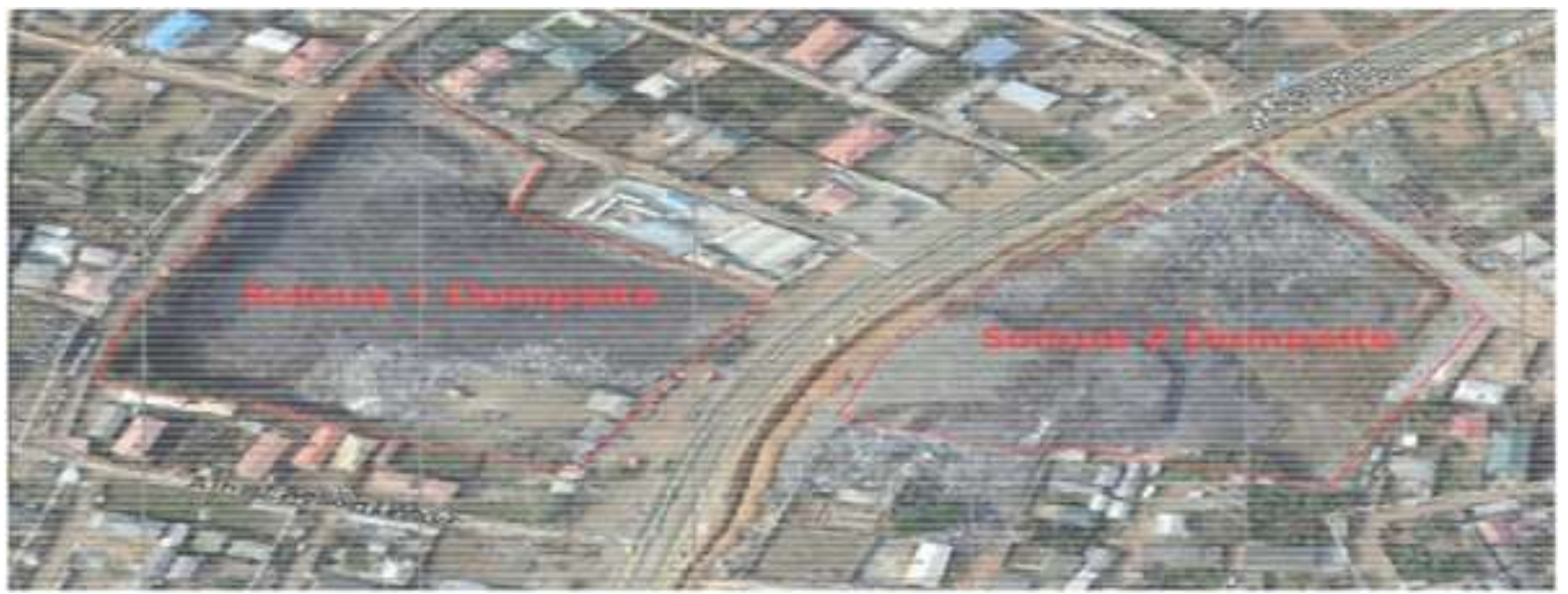

Figure 4: Location of Soluos 1 and 2 dumpsites

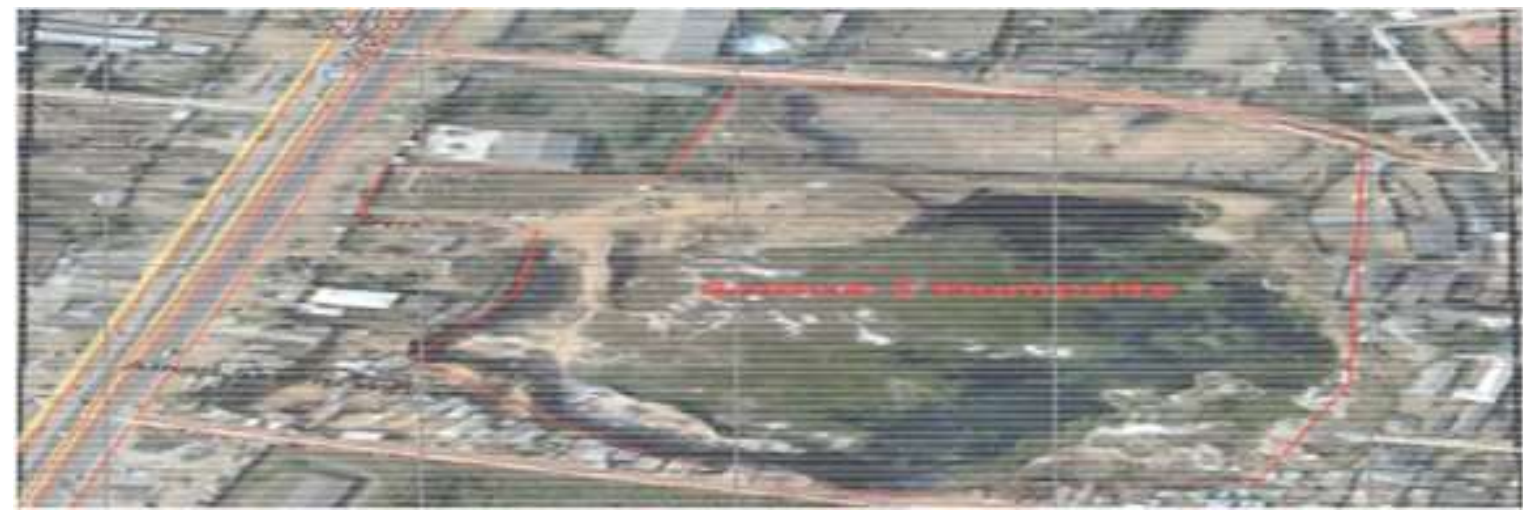

Figure 5: Location of Soluos 3 dumpsite 


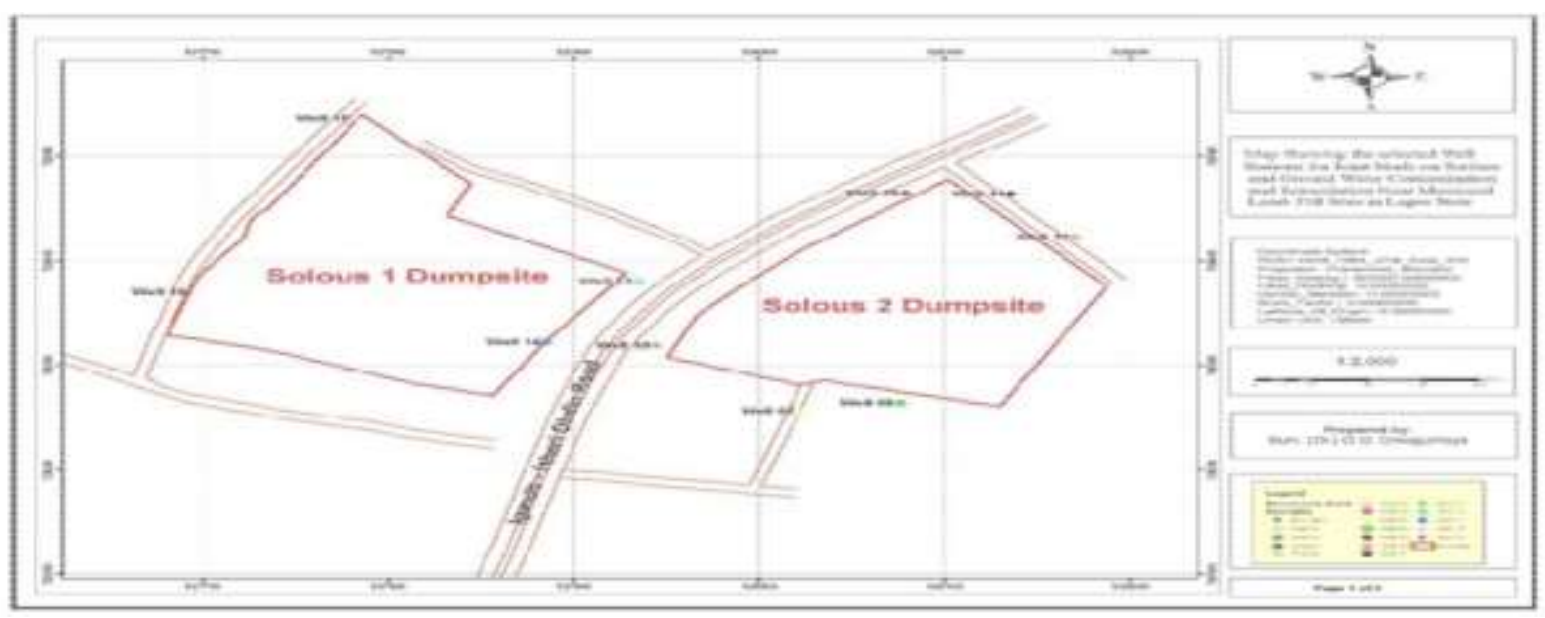

Figure 6: Final plan of the project site overlaid on the satellite imagery for Soluos 1 and 2 dumpsites

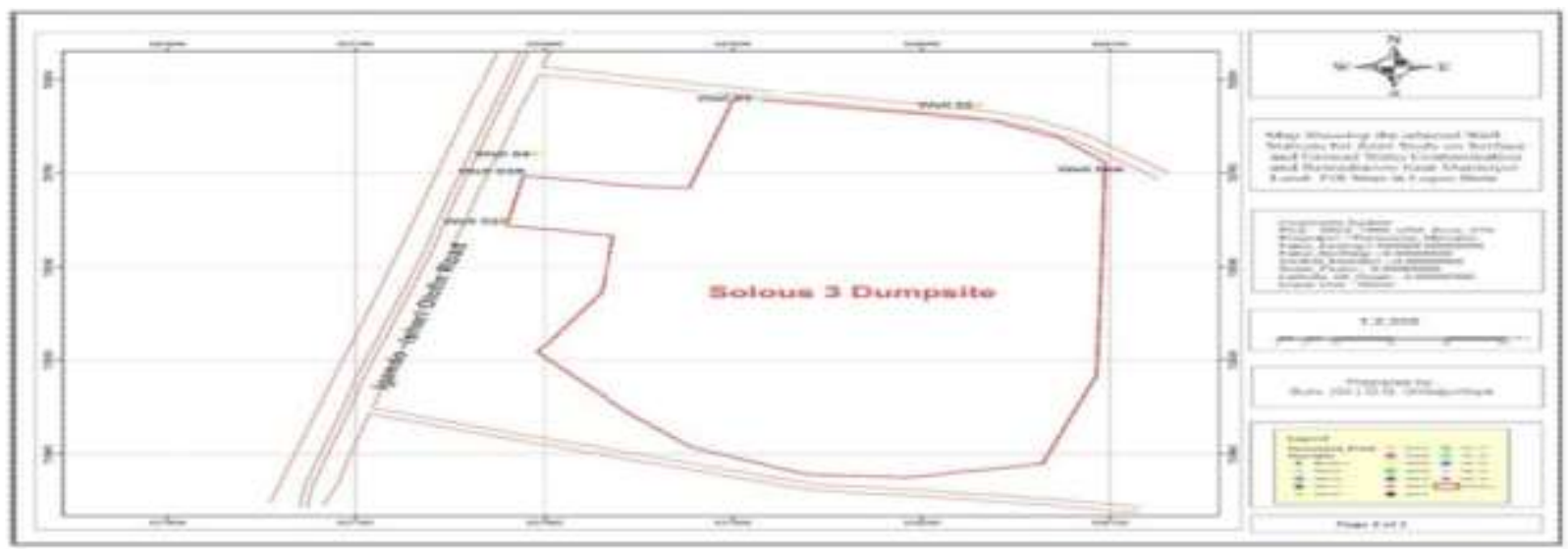

Figure 7: Final plan of the project site overlaid on the satellite imagery for Soluos 3

\subsection{Sampling and Analysis}

Leachate samples were collected using 1-litreplastic bottles that had been cleaned by soaking in $10 \%$ nitric acid and rinsed with distilled water in order to avoid contamination and allowed to dry before use. In each of the sampling site, the treated bottles were rinsed twice with leachate to be sampled prior to filling to avoid dilution. In Soluos 1 dumpsite, leachate samples were taken in the month of August, 2014. Since the dumpsites were not equipped with leachate collector system, leachates were sampled from the four extremes of dump site using the treated bottles labeled LS 11, LS 12, LS 13 and LS 14. The samples were then transferred to the laboratory in an ice cooler and stored in cold room at a temperature of $4^{\circ} \mathrm{C}$. Prior to analysis, the samples were allowed to return to room temperature and measurement for leachate parameters was carried out. The same procedure was followed for Soluos 2 and 3 dumpsites. The leachate samples from Soluos 2 were labeled LS 21, LS 22, LS 23 and LS 24 while leachate samples from Soluos 3 were labeled LS31, LS32, LS33 and LS34. s 1, 2 and 3showed the parameters measured for each dumpsite. All the parameters were measured according to the standard method for the examination of water and wastewater by APHA, in the analytical laboratory of Bato Chemicals Limited, Lagos. All experiments were carried out in triplicate and the results were found reproducible within $\pm 3 \%$ error.

\subsection{RESULTS AND DISCUSSION}

The characteristics of leachate are dependent primarily on the waste composition and its water content. The characteristics of leachate samples collected from the Soluos 1, 2 and 3 dumpsites are presented in Tables 1, 2 and 3 respectively while table 4 showed the guidelines for permissible limit for discharge of leachate into surface water. Tables 5 and 6 presented the correlation matrices of leachate parameters for Soluos 1 and 2 dumpsites while Table 7 provided the correlation matrix for Soluos 3 dumpsite. These correlations were developed using the in-built Pearson product moment correlation coefficient solver tool in Microsoft Excel version 7 . The parameters correlated were taken from 
Table 4, which were the parameters presented by the regulatory bodies.

The $\mathrm{pH}$ of leachate samples collected from Soluos 3 ranged between 4.8 and 5.12 that of Solous 1 ranged between 7.2 and 7.8 while the ones from Soluos 2 ranged between 7.15 and 7.59 . Soluos 2 has the highest $\mathrm{pH}$ range while Soluos 3 has the least $\mathrm{pH}$ range. Leachate is generally found to have $\mathrm{pH}$ levels between 4.5 and 9 (Christensen et al., 2001). The pH of leachate samples from all the three dumpsites in Soluos varied between 4.8 and 7.8 which fall within the range reported by Christensen et al. (2001). The $\mathrm{pH}$ of a young leachate is less than 6.5 while old landfill leachate has $\mathrm{pH}$ higher than 7.5 (Abbas, et al., 2009). According to Abbas et al. (2009), leachate samples from Soluos 3 which ranged between 4.8 and 5.2 can be described as young leachate while leachate samples collected from Soluos 1 and 2 which varied between 7.2 and 7.8 and between 7.15 and 7.59 respectively can be described relatively as old leachate. This result is in consonance with the age of these dumpsites which puts the age of Soluos 3 as 9 years, therefore young, and Solous 1 and 2 as 21 and 19 years respectively which make Soluos 1 and 2 older than Soluos 3.

The TDS of leachate samples from Soluos 3 ranged from 459 to $649 \mathrm{mg} / \mathrm{L}$ that of Soluos 1 range from 1092 to $5810 \mathrm{mg} / \mathrm{L}$ while leachate samples from Soluos 2 ranged from 817 to $3090 \mathrm{mg} / \mathrm{L}$. Among all the three dumpsites, Soluos 1 has the highest range in term of TDS while Soluos 3 has the least range. Total dissolved solids (TDS) comprises mainly of inorganic salts and dissolved organics (Muhammed et al., 2010). The amount of TDS reflects the extent of mineralization and a higher TDS concentration can change the physical and chemical characteristics of receiving water (AlYaqout and Hamoda, 2003). Comparing the TDS of the three dumpsites, Soluos 1 has the highest range while Soluos 3 has the least range. This revealed that Soluos 1 has the highest mineralization while Soluos 3 has the least mineralization. The increase in salinity due to increase in TDS concentration also increases toxicity by changing the ionic composition of water. Soluos 1 having the highest TDS among the dumpsites is likely to have the highest toxicity level.

The BOD for Soluos 1 and 2 ranged between 100 and $760 \mathrm{mg} / \mathrm{L}$ and between 100 and $327 \mathrm{mg} / \mathrm{L}$ respectively while that of Soluos 3 varied between 912 and $1483 \mathrm{mg} / \mathrm{L}$. The COD for Soluos 1 and 2 ranged between 300 and $1636 \mathrm{mg} / \mathrm{L}$ and between 150 and 1080 respectively while that of Soluos 3 varied between 945 and $1023 \mathrm{mg} / \mathrm{L}$. The high BOD and COD of the leachate samples collected from the dumpsites indicated the leachates were at the acidogenic biodegradation stage. During the methanogenic phase, the organic strength of the leachate will be reduced by methanogenicarchaea. Comparing all the three dumpsites, Soluos 1 has the highest BOD and COD values, followed by Soluos 2 while Soluos 3 has the least values of BOD and COD. A closed dumpsite is suitable for organic activities. This may be attributed to why Soluos 1 which is a closed dumpsite has the highest BOD and COD values.

The ammoniacal nitrogen (AN) ranged between 24.7 and $226.4 \mathrm{mg} / \mathrm{L}$ for Soluos 1 , between 26.3 and $36.3 \mathrm{mg} / \mathrm{L}$ for Soluos 2 and between 7.98 and 8.77 for Soluos 3. Ammonium represents the major proportion of total nitrogen. In comparison to soluble organics, the release of soluble nitrogen from waste into leachate continues over longer period (Kulikowska and Klimiuk, 2008). The concentration of ammoniacal nitrogen in the dumpsite leachates will increase with an increase in the age of the dumpsites due to hydrolysis and fermentation of nitrogenous fractions of biodegradable refuse substrates. Ammonia is considered as a major long-term pollutant because of its stability under anaerobic conditions (Kulikowska and Klimiuk, 2008; Tatsi and Zouboulis, 2002; Statom et al., 2004 and Marttinen et al., 2003). Ammonia concentration differs highly in leachates from different landfills as depicted in the Soluos dumpsites. According to Liand Zhao (2002), ammoniacal nitrogen in stabilized leachate might range between $3,000-5,000 \mathrm{mg} / \mathrm{L}$. None of the leachates from the Soluos dumpsites falls within this range which indicates that the leachates in the Soluos dumpsites are not at the stabilized stage. Ammoniacal nitrogen is ranked as a major toxicant to living organisms, as established by various toxicity analyses using bioassays and various test organisms such as salmogairdnieri and oncorhychusnerka (Kurniawan et al., 2006). Higher concentrations of ammonia are also known to enhance algae growth, promote eutophication due to decreased dissolved oxygen (Kurniawan et al., 2006). The low concentration of ammoniacal nitrogen in the sampled leachates depict the likelihood of the Soluos dumpsite leachate not to enhance algae growth, and not to promote eutrophication.

In Soluos 1, the concentration of cadmium, lead and chromium were less than 0.001 in all the samples analyzed, copper ranged from 0.11 to $0.74 \mathrm{mg} / \mathrm{L}$, zinc varied between 0.174 and $1.823 \mathrm{mg} / \mathrm{L}$ while boron ranged between 0.002 and $0.005 \mathrm{mg} / \mathrm{L}$. In Soluos 2, cadmium fell in the range between 0.005 and 0.022 $\mathrm{mg} / \mathrm{L}$, the highest values of chromium and copper were 0.002 and $0.315 \mathrm{mg} / \mathrm{L}$ respectively. Lead and nickel have the highest values of 0.0013 and $0.005 \mathrm{mg} / \mathrm{L}$ respectively. Zinc varied between 0.0026 and $0.0052 \mathrm{mg} / \mathrm{L}$ while boron also was in the range of concentrations of zinc. In Soluos 3 , cadmium has a concentration of $0.003 \mathrm{mg} / \mathrm{L}$ among the samples investigated, chromium ranged between 3.99 and $5.03 \mathrm{mg} / \mathrm{L}$, copper varied between 3.89 and $4.978 \mathrm{mg} / \mathrm{L}$, Iron was between 8 and $13 \mathrm{mg} / \mathrm{L}$, lead ranged between 2.98 and $3.78 \mathrm{mg} / \mathrm{L}$, nickel varied between 3.85 and 4.78 $\mathrm{mg} / \mathrm{L}$, zinc range between 4.991 and $6.01 \mathrm{mg} / \mathrm{L}$ and boron varied between 0.004 and $0.007 \mathrm{mg} / \mathrm{L}$.

In general, the concentration of heavy metals in landfill leachate is fairly low (Christensen et al., 2001). Concentration of heavy metals in a landfill is generally higher at earlier stages because of higher metal solubility as a result of low $\mathrm{pH}$ caused by production of 
organic acids (Kulikowska and Klimiuk, 2008). The low concentration of heavy metals in the leachates in all the three dumpsites were in line with the findings of previous researcher workson other dumpsites (Christensen etal., 2001 and Kjelden and Christophersen, 2001). The presence of zinc in the leachates from the Soluos dumpsites reveals that the dumpsites receive wastes from batteries and fluorescent lamps. The presence of lead in the leachate samples indicates the disposal of lead batteries, chemicals for photograph processing, lead-based paints and pipes at the dumpsites. A variety of waste is dumped at the Soluos dumpsites which likely indicate the source of zinc, chromium, copper, lead, nickel and boron in the dumpsite leachates.

The concentration of total phenol in Soluos 1 varied between 0.1 and $0.22 \mathrm{mg} / \mathrm{L}$. The concentrations of total phenol were less than $0.001 \mathrm{mg} / \mathrm{L}$ in all the samples from Soluos 2 while the concentrations of total phenol in Soluos 3 ranged between 0.03 and $0.2 \mathrm{mg} / \mathrm{L}$. Phenolic compounds are readily degradable under aerobic condition while degradation under anaerobic conditions is uncertain (Christensen etal., 2001). The values of total phenol in all the three dumpsites are less than $0.23 \mathrm{mg} / \mathrm{L}$. The Soluos dumpsites are open dumpsites which affords abundant oxygen availability at the sites. As a result, there is a high chance of degradation of phenolic compounds in the Soluos dumpsites. This is attributed to the low values of total phenol in all the Soluos dumpsite. However, the concentration of chlorides ranged between 358 and $1131 \mathrm{mg} / \mathrm{L}$ in Soluos 1 while in Soluos 2, the concentration of chlorides varied between 410 and 2175 $\mathrm{mg} / \mathrm{L}$. In Soluos 3, the concentration of chlorides ranged between 346.39 and $456.34 \mathrm{mg} / \mathrm{L}$.

The high values of chlorides in all the dumpsites are as a result of the fact that chlorides are not attenuated by soil and are extremely mobile under all conditions.

In terms of microbiological evaluation, in Soluos 1, the coliforms and Ecoli varied between 6 and 210 $\mathrm{Cfu} / \mathrm{ml}$ and between 4 and $160 \mathrm{Cfu} / \mathrm{mL}$ respectively while total plate count was too numerous to count. In Soluos 2, the coliforms and Ecoli ranged between 16 and $75 \mathrm{CFU} / \mathrm{ml}$ and between 2 and $15 \mathrm{Cfu} / \mathrm{ml}$ respectively while the AMC was too numerous to count. In Soluos 3, the coliforms and Ecoli varied from 39 to 44 $\mathrm{Cfu} / \mathrm{ml}$ and 12 to $24 \mathrm{Cfu} / \mathrm{ml}$ respectively while the total plate count (AMC) was too numerous to count. Soluos 1 has the highest coliforms and Ecoli among the dumpsites. The presence of coliforms, Ecoli and AMC is pointer to the contamination potential of the leachate. This indicates that leachate from Soluos1 dumpsite has the highest contamination potential towards soil, vegetation, surface and groundwater. This is also due to the fact that Soluos 1 is a closed dumpsite and a closed dumpsite provides an opportunity for enhanced microbiological activities.

The general appearance of all the leachates collected from the three dumpsites in Soluos was brownish in colour and the odour of the leachates was objectionable. The electrical conductivity varied between 2446 and 10,452 Us/cm for Soluos 1, between 1621 and $6140 \mathrm{Us} / \mathrm{cm}$ for Soluos 2 and between 2987 to 3145 Us/cm for Soluos 3. Among all the leachate samples investigation, Soluos 1 has the widest range in term of electrical conductivity. The relatively high values of electrical conductivity indicate the presence of inorganic material in the samples. This revealed that Soluos 1 has the highest level of inorganic materials. Comparing parameters in Tables1, 2 and 3 with the guidelines for permissible limit for discharge of leachate to inland surface water presented in Table 4, some parameters exceeded the permissible limits. These include BOD, COD, TDS, copper, lead and chromium which reveals that the leachate from Soluos dumpsites should be treated especially the leachate from Soluos 3 dumpsite.

Correlation analysis is a preliminary descriptive technique to estimate the degree of association among the parameters involved in a study (Suman et al., 2006). The purpose of the correlation analysis is to measure the intensity of association observed between two variables. Such association is likely to lead to reasoning about causal relationship between the variables (Suman et al., 2006). A correlation value $(r)$ is such that $-1 \leq R \leq+1$. The positive correlation means that an increase in one variable leads to an increase in another variable while a negative correlation means that an increase in one particular variable result to a decrease in another variable. A correlation value of zero means there is no correlation between the variables. A correlation value greater than 0.8 is generally described as strong whereas a correlation value less than 0.5 is generally described as weak. A correlation value between 0.5 and 0.8 can be described as moderate.(Kumar et al., 2007 and Kurumbein and Graybill, 1965).

In Table 5, all the parameters can be said to be strongly correlated. In Table 6 , majority of the parameters are strongly correlated while in Table 7 , some of the parameters are also strongly correlated. The strong correlation exhibited by the leachate parameters in all the three Soluos dumpsites is an indication that the waste compositions of the three Soluos dumpsites are similar. The strong correlation by the leachate parameters in the Soluos dumpsites is also a preliminary indication that the particle size of waste, degree of compaction of waste, hydrology of the dumpsites, moisture content and available oxygen in the Soluos dumpsite are also similar. The strong correlation exhibited by leachate parameters from the Soluos dumpsites is in line with the previous works of Milke and Huitric (1993), Ogundiran and Afolabi (2008), Adedose et al., (2013) and Wijesekara et al. (2014).

The strong correlation among the leachate parameters of Soluos dumpsite would suggest that the current practice of waste mix in the dumpsite is unhelpful; this practice should be discontinued. There should be different sections for industrial, medical, domestic, hazardous and municipal wastes. It is also imperative that the existing leachates in the dumpsites should be treated. However, all the leachate parameters 
used for correlation were totally correlated for Soluos 1 dumpsite unlike Soluos 2 and 3 dumpsites where not all the parameters were totally correlated although the majority of the parameters were correlated. This may be attributed to the fact that Soluos 1 dumpsite is the oldest among the Soluos dumpsites and is also a closed dumpsite while Soluos 2 and 3 dumpsites are still active.

This work is entirely different from the previous works done on leachates from dumpsites by some researchers. A comprehensive study of leachate characteristics has been carried out by considering thirty six leachate parameters unlike the previous works of
Reinhart and Grosh (1998), Kumar and Alappat (2003), Alimbat et al. (2006), Ogundiran and Afolabi (2008), Longe and Balogun (2010), Aderemi et al. (2011), Afolayan et al. (2012), Adedose (2013) and Olubunmi (2013) who only considered much fewer leachates parameters. The comprehensive study of the leachates from dumpsites gives a proper understanding of the characteristics of the leachates. This work has presented an in-depth characteristics and behavior of leachates from Soluos dumpsites in Igando area of Lagos State which is crucial for the planning of waste mix in Lagos State by the state government.

Table 1: Characteristics of leachate samples from Soluos 1 dumpsite

\begin{tabular}{|c|c|c|c|c|c|}
\hline $\mathrm{S} / \mathrm{N}$ & Parameters (mg/L) & LS 11 & LS 12 & LS 13 & LS 14 \\
\hline 1 & General appearance & Brownish & Brownish & Brownish & Brownish \\
\hline 2 & True colour $(\mathrm{Hz})$ & 35 & 50 & 25 & 45 \\
\hline 3 & Odour & $\overline{\mathrm{OB}}$ & OB & OB & OB \\
\hline 4 & Electrical conductivity (Us/cm) & 2492 & 9447 & 2446 & 10452 \\
\hline 5 & $\mathrm{pH} @ 25^{\circ} \mathrm{C}$ & 7.2 & 7.8 & 7.4 & 7.8 \\
\hline 6 & Total dissolved solids & 1280 & 3996 & 1092 & 5810 \\
\hline 7 & Total solids & 1426 & 4476 & 2316 & 6364 \\
\hline 8 & Total hardness-EDTA & 205.3 & 548.7 & 127.4 & 424.8 \\
\hline 9 & Total alkalinity & 498.2 & 2707.9 & 630.3 & 2660.7 \\
\hline 10 & Ammoniacal nitrogen & 24.7 & 221.2 & 102.9 & 226.4 \\
\hline 11 & Chloride & 358.1 & 730.5 & 243.5 & 1131.6 \\
\hline 12 & Nitrate & 1.0 & 0.5 & 3.0 & 0.5 \\
\hline 13 & Nitrite & 0.02 & 0.01 & 5.0 & 0.01 \\
\hline 14 & Total phosphate & 2.3 & 24.1 & 18.7 & 24.1 \\
\hline 15 & Sulphate & 63 & 129.2 & 78.8 & 220.5 \\
\hline 16 & Silica & 12 & 9 & 10 & 8.5 \\
\hline 17 & Cadmium & $<0.001$ & $<0.001$ & $<0.001$ & $k 0.001$ \\
\hline 18 & Calcium & 191.2 & 539.9 & 115.1 & 416 \\
\hline 19 & Chromium & $<0.001$ & $<0.001$ & $<0.001$ & $<0.001$ \\
\hline 20 & Copper & 0.11 & 0.131 & 0.175 & 0.74 \\
\hline 21 & Iron & 6.2 & 9.6 & 1.2 & 10.8 \\
\hline 22 & Lead & $<0.001$ & $k 0.001$ & $<0.001$ & $k 0.001$ \\
\hline 23 & Magnesium & 3.4 & 2.2 & 3.0 & 2.2 \\
\hline 24 & Manganese & 1.071 & 0.935 & 0.182 & 0.831 \\
\hline 25 & Sodium & 232.3 & 491.8 & 157.9 & 792.1 \\
\hline 26 & Potassium & 146.5 & 171.3 & 233.5 & 209.6 \\
\hline 27 & Nickel & $<0.001$ & $<0.001$ & $<0.001$ & $k 0.001$ \\
\hline 28 & Fluoride & $<0.001$ & $k 0.001$ & $<0.001$ & $k 0.001$ \\
\hline 29 & Zinc & 0.174 & 0.311 & 0.248 & 1.823 \\
\hline 30 & Phenol & 0.18 & 0.14 & 0.1 & 0.22 \\
\hline 31 & Boron & 0.0037 & 0.004 & 0.003 & 0.002 \\
\hline 32 & Biochemical oxygen demand & 100 & 570 & 120 & 760 \\
\hline 33 & Chemical oxygen demand & 150 & 810 & 180 & 1080 \\
\hline 34 & Coliform (Cfu/ml) & 80 & 240 & 6 & 210 \\
\hline 35 & Ecoli (Cfu/ml) & 20 & 42 & 4 & 160 \\
\hline 36 & Aerobic mesophilic count & TNTC & TNTC & TNTC & TNTC \\
\hline
\end{tabular}

Note: pH has no unit; OB means objectionable; TNTC means too numerous to count 
Table 2: Characteristics of leachate samples from Soluos 2 dumpsite

\begin{tabular}{|c|c|c|c|c|c|}
\hline $\mathrm{S} / \mathrm{N}$ & Parameters $(\mathrm{mg} / \mathrm{L})$ & LS 21 & LS 22 & LS 23 & LS 24 \\
\hline 1 & General appearance & Brownish & Brownish & Brownish & Brownish \\
\hline 2 & True colour $(\mathrm{Hz})$ & 50 & 50 & 50 & 50 \\
\hline 3 & Odour & OB & OB & OB & $\mathrm{OB}$ \\
\hline 4 & Electrical conductivity $(\mathrm{Us} / \mathrm{cm})$ & 5360 & 6140 & 4611 & 1621 \\
\hline 5 & $\mathrm{pH} @ 25^{\circ} \mathrm{C}$ & 7.49 & 7.49 & 7.59 & 7.15 \\
\hline 6 & Total dissolved solids & 2690 & 3090 & 2301 & 817 \\
\hline 7 & Total solids & 5642 & 6543 & 4501 & 874 \\
\hline 8 & Total hardness-EDTA & 196.39 & 400.8 & 501 & 86.17 \\
\hline 9 & Total alkalinity & 5000 & 5900 & 600 & 250 \\
\hline 10 & Ammoniacal nitrogen & 26.30 & 28.80 & 36.30 & 35.20 \\
\hline 11 & Chloride & 2175 & 2000 & 500 & 410 \\
\hline 12 & Nitrate & 1.2 & 1.3 & 1.2 & 0.02 \\
\hline 13 & Nitrite & 3.2 & 3.28 & 2.0 & 1.06 \\
\hline 14 & Total phosphate & 33.7 & 32.1 & 35.1 & 7.2 \\
\hline 15 & Sulphate & 320 & 260 & 240 & 300 \\
\hline 16 & Silica & 726 & 693 & 623 & 540 \\
\hline 17 & Cadmium & 0.021 & 0.022 & 0.005 & 0.018 \\
\hline 18 & Calcium & 320.6 & 686.17 & 1122.24 & 480.90 \\
\hline 19 & Chromium & $<0.001$ & $k 0.001$ & $<0.001$ & $k 0.001$ \\
\hline 20 & Copper & 0.203 & 0.15 & 0.315 & 0.201 \\
\hline 21 & Iron & 17 & 12 & 15 & 7 \\
\hline 22 & Lead & $<0.001$ & $<0.001$ & $k 0.001$ & $<0.001$ \\
\hline 23 & Magnesium & 448.5 & 545.85 & 524.86 & 176.50 \\
\hline 24 & Manganese & 39.43 & 47.32 & 34.46 & 13.00 \\
\hline 25 & Sodium & 28.54 & 29.16 & 24.92 & 30.04 \\
\hline 26 & Potassium & 47.03 & 41.31 & 46.52 & 17.65 \\
\hline 27 & Nickel & $<0.001$ & $<0.001$ & $<0.001$ & $<0.001$ \\
\hline 28 & Fluoride & 0.025 & 0.018 & 0.021 & 0.006 \\
\hline 29 & Zinc & 0.0052 & 0.0026 & 0.004 & 0.0031 \\
\hline 30 & Phenol & $<0.001$ & $<0.001$ & $<0.001$ & $<0.001$ \\
\hline 31 & Boron & 0.005 & 0.0026 & 0.004 & 0.0031 \\
\hline 32 & Biochemical oxygen demand & 316 & 327 & 268 & 100 \\
\hline 33 & Chemical oxygen demand & 1579 & 1636 & 1338 & 300 \\
\hline 34 & Coliform (Cfu/ml) & 66 & 75 & 25 & 16 \\
\hline 35 & Ecoli (Cfu/ml) & 7 & 15 & 2 & 5 \\
\hline 36 & Aerobic mesophilic count & TNTC & TNTC & TNTC & TNTC \\
\hline
\end{tabular}

Note: pH has no unit; OB means objectionable; TNTC means too numerous to count 
Table 3: Characteristics of leachate samples from Soluos 3 dumpsite

\begin{tabular}{|c|c|c|c|c|c|}
\hline $\mathrm{S} / \mathrm{N}$ & Parameters $(\mathrm{mg} / \mathrm{L})$ & LS 31 & LS 32 & LS 33 & LS 34 \\
\hline 1 & General appearance & Brownish & Brownish & Brownish & Brownish \\
\hline 2 & True colour $(\mathrm{Hz})$ & 40 & 38 & 43 & 36 \\
\hline 3 & Odour & OB & OB & OB & OB \\
\hline 4 & Electrical conductivity (Us/cm) & 3145 & 3412 & 2987 & 3091 \\
\hline 5 & $\mathrm{pH} @ 25^{\circ} \mathrm{C}$ & 4.9 & 5.12 & 4.8 & 5.1 \\
\hline 6 & Total dissolved solids & 649 & 459 & 605.34 & 600 \\
\hline 7 & Total solids & 1567 & 1674 & 2009 & 1240 \\
\hline 8 & Total hardness-EDTA & 489 & 600.67 & 589.12 & 500 \\
\hline 9 & Total alkalinity & 1267 & 1220 & 1129.67 & 989.23 \\
\hline 10 & Ammoniacal nitrogen & 8.77 & 8.56 & 7.98 & 8.50 \\
\hline 11 & Chloride & 346.39 & 389.67 & 400.02 & 456.34 \\
\hline 12 & Nitrate & 0.87 & 0.89 & 0.79 & 0.85 \\
\hline 13 & Nitrite & 3.01 & 3.07 & 3.67 & 4.04 \\
\hline 14 & Total phosphate & 98.67 & 102.34 & 99.89 & 98.34 \\
\hline 15 & Sulphate & 104 & 89.87 & 118 & 107 \\
\hline 16 & Silica & 45 & 47.45 & 40.98 & 42 \\
\hline 17 & Cadmium & 0.003 & 0.003 & 0.003 & 0.003 \\
\hline 18 & Calcium & 120.56 & 124.45 & 130.87 & 126.45 \\
\hline 19 & Chromium & 49.68 & 3.99 & 4.897 & 5.03 \\
\hline 20 & Copper & 4.987 & 3.89 & 4.12 & 4.01 \\
\hline 21 & Iron & 8.543 & 11.23 & 12 & 9.76 \\
\hline 22 & Lead & 3.446 & 3.78 & 2.98 & 3.56 \\
\hline 23 & Magnesium & $<0.001$ & $<0.001$ & $k 0.001$ & $<0.001$ \\
\hline 24 & Manganese & 2.6 & 2.64 & 2.99 & 2.87 \\
\hline 25 & Sodium & 154.67 & 134.98 & 150 & 147.12 \\
\hline 26 & Potassium & 56.89 & 47.34 & 49.23 & 57.87 \\
\hline 27 & Nickel & 3.991 & 4.23 & 4.78 & 3.85 \\
\hline 28 & Fluoride & $<0.001$ & $<0.001$ & $<0.001$ & $<0.001$ \\
\hline 29 & Zinc & 4.991 & 5.23 & 6.01 & 5.24 \\
\hline 30 & Phenol & 0.13 & 0.003 & 0.17 & 0.2 \\
\hline 31 & Boron & 0.004 & 0.007 & 0.004 & 0.005 \\
\hline 32 & Biochemical oxygen demand & 1396 & 1483 & 912 & 1465 \\
\hline 33 & Chemical oxygen demand & 946 & 1023 & 983 & 945 \\
\hline 34 & Coliform (Cfu/ml) & 46 & 49 & 39 & 44 \\
\hline 35 & Ecoli (Cfu/ml) & 18 & 12 & 21 & 24 \\
\hline 36 & Aerobic mesophilic count & TNTC & TNTC & TNTC & TNTC \\
\hline
\end{tabular}

Note: $\mathrm{pH}$ has no unit; OB means objectionable; TNTC means too numerous to count 
Table 4: Guidelines for permissible limit for discharge of leachate into surface water

\begin{tabular}{|l|l|l|l|}
\hline & Parameters $(\mathrm{mg} / \mathrm{L})$ & ${ }^{\mathrm{a}}$ FEPA & ${ }^{\mathrm{b}}$ India \\
\hline & & & \\
\hline 1 & Chromium & $<1$ & 2.0 \\
\hline 2 & Lead & $<1$ & 0.1 \\
\hline 3 & Chemical oxygen demand & - & 250 \\
\hline 4 & Mercury & 0.05 & 0.01 \\
\hline 5 & Biochemical oxygen demand & 30 & 30 \\
\hline 6 & Arsenic & 5 & 0.2 \\
\hline 7 & Cyanide & 0.2 & 0.2 \\
\hline 8 & Phenol & 5 & 1.0 \\
\hline 9 & Zinc & $<1$ & 5.0 \\
\hline 10 & pH & $6-9$ & $5.5-9.0$ \\
\hline 11 & Total Kjeldahl nitrogen & - & 100 \\
\hline 12 & Nickel & $<1$ & 3.0 \\
\hline 13 & Total coliform & 400 & - \\
\hline 14 & Ammonia nitrogen & - & 50 \\
\hline 15 & Total dissolved solids & 30 & 2100 \\
\hline 16 & Copper & $<1$ & 3.0 \\
\hline 17 & Chlorides & - & 3.0 \\
\hline 18 & Iron & 10 & - \\
\hline 19 & Pesticides & $<0.01$ & - \\
\hline
\end{tabular}

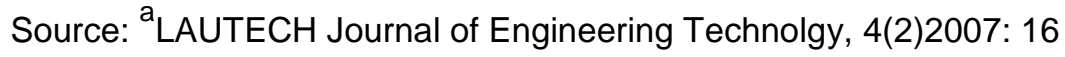

Table 5: Correlation matrix of leachate parameters for Soluos 1 dumpsite

\begin{tabular}{|l|l|l|l|l|l|l|l|l|l|l|l|}
\hline Parameters & COD & BOD & Phenol & $\mathrm{Zn}$ & $\mathrm{pH}$ & $\mathrm{TDS}$ & $\mathrm{AN}$ & $\mathrm{Cu}$ & $\mathrm{Cl}$ & $\mathrm{Fe}$ & Coliform \\
\hline $\mathrm{COD}$ & 1.00 & & & & & & & & & & \\
\hline BOD & 0.99 & 1.00 & & & & & & & & & \\
\hline Phenol & 0.56 & 0.57 & 1.00 & & & & & & & & \\
\hline $\mathrm{Zn}$ & 0.79 & 0.79 & 0.75 & 1.00 & & & & & & & \\
\hline $\mathrm{pH}$ & 0.94 & 0.94 & 0.26 & 0.61 & 1.00 & & & & & & \\
\hline $\mathrm{TDS}$ & 0.99 & 0.99 & 0.65 & 0.84 & 0.90 & 1.00 & & & & & \\
\hline $\mathrm{AN}$ & 0.93 & 0.93 & 0.23 & 0.62 & 0.99 & 0.89 & 1.00 & & & & \\
\hline $\mathrm{Cu}$ & 0.74 & 0.74 & 0.72 & 0.99 & 0.56 & 0.80 & 0.58 & 1.00 & & & \\
\hline $\mathrm{Cl}$ & 0.97 & 0.97 & 0.74 & 0.88 & 0.84 & 0.99 & 0.83 & 0.83 & 1.00 & & \\
\hline Fe & 0.86 & 0.86 & 0.76 & 0.62 & 0.71 & 0.88 & 0.67 & 0.54 & 0.89 & 1.00 & \\
\hline Coliform & 0.89 & 0.89 & 0.53 & 0.50 & 0.84 & 0.86 & 0.81 & 0.42 & 0.85 & 0.95 & 1.00 \\
\hline
\end{tabular}


Table 6: Correlation matrix of leachate parameters for Soluos 2 dumpsite

\begin{tabular}{|l|l|l|l|l|l|l|l|l|l|l|}
\hline Parameters & COD & BOD & $\mathrm{Zn}$ & $\mathrm{pH}$ & TDS & $\mathrm{AN}$ & $\mathrm{Cu}$ & $\mathrm{Cl}$ & $\mathrm{Fe}$ & Coliform \\
\hline $\mathrm{COD}$ & 1.00 & & & & & & & & & \\
\hline BOD & 0.99 & 1.00 & & & & & & & & \\
\hline $\mathrm{Zn}$ & 0.31 & -0.08 & 1.00 & & & & & & & \\
\hline $\mathrm{pH}$ & 0.90 & 0.71 & 0.36 & 1.00 & & & & & & \\
\hline $\mathrm{TDS}$ & 0.99 & 0.99 & 0.18 & 0.85 & 1.00 & & & & & \\
\hline AN & -0.64 & -0.67 & 0.34 & 0.26 & -0.66 & 1.00 & & & & \\
\hline $\mathrm{Cu}$ & -0.05 & -0.09 & 0.36 & 0.38 & -0.17 & 0.65 & 1.00 & & & \\
\hline $\mathrm{Cl}$ & 0.75 & 0.78 & 0.26 & 0.40 & -0.78 & -0.98 & -0.62 & 1.00 & & \\
\hline Fe & 0.83 & 0.82 & 0.76 & 0.87 & 0.74 & -0.48 & 0.33 & 0.53 & 1.00 & \\
\hline Coliform & 0.81 & 0.83 & 0.10 & 0.47 & 0.86 & -0.92 & -0.62 & 0.98 & 0.49 & 1.00 \\
\hline
\end{tabular}

Table 7: Correlation matrix of leachate parameters for Soluos 3 dumpsite

\begin{tabular}{|c|c|c|c|c|c|c|c|c|c|c|c|}
\hline Parameters & COD & BOD & Phenol & $\mathrm{Zn}$ & $\mathrm{pH}$ & TDS & AN & $\mathrm{Cu}$ & $\mathrm{Cl}$ & $\mathrm{Fe}$ & Coliform \\
\hline COD & 1.00 & & & & & & & & & & \\
\hline BOD & $-0-07$ & 1.00 & & & & & & & & & \\
\hline Phenol & -0.82 & -0.38 & 1.00 & & & & & & & & \\
\hline $\mathrm{Zn}$ & 0.27 & -0.92 & 0.30 & 1.00 & & & & & & & \\
\hline $\mathrm{pH}$ & 0.23 & 0.85 & -0.41 & -0.58 & 1.00 & & & & & & \\
\hline TDS & -0.90 & -0.33 & 0.83 & 0.04 & 0.64 & 1.00 & & & & & \\
\hline AN & -0.25 & 0.89 & -0.34 & -0.99 & 0.51 & 0.03 & 1.00 & & & & \\
\hline $\mathrm{Cu}$ & -0.59 & 0.04 & 0.18 & 0.42 & 0.49 & 0.70 & 0.49 & 1.00 & & & \\
\hline$\overline{\mathrm{Cl}}$ & -0.13 & 0.06 & 0.44 & 0.24 & 0.45 & 0.12 & -0.34 & -0.73 & 1.00 & & \\
\hline $\mathrm{Fe}$ & 0.74 & -0.60 & -0.22 & 0.83 & -0.14 & -0.53 & -0.83 & -0.75 & 0.26 & 1.00 & \\
\hline Coliform & 0.31 & 0.89 & -0.76 & -0.83 & 0.73 & 0.57 & 0.84 & 0.05 & -0.27 & 0.39 & 1.00 \\
\hline
\end{tabular}

\subsection{CONCLUSION}

We have presented the results of a comprehensive investigation of the leachates from three Soluos dumpsites in close proximity and found a variation in the parameters of the leachates despite the fact that they are they are located in the same community. Some parameters such as BOD, COD, TDS, copper and chromium exceeded the stipulated permissible limits by regulatory bodies. Correlation analysis was carried out to measure the degree of association among the leachate parameters. This shows that there is a strong relationship among the waste components in the dumpsites. It is therefore recommended that the current practise of waste mix in the dumpsites should be stopped and the dumpsites leachates should be treated.

\section{REFERENCES}

Abbas, A. A. Jingsong, G., Ping, L. Z., Ya, P. Y. and AlRekabi, W. S. (2009). "Review on landfill Leachate treatments", Journal of Applied Science Research, 5 (5): 209-217.

Adedosu, H.O. Adewuyi, G.O. and Adie, G.U. (2013)."Assessment of heavy metals in soil, leachate and underground water samples collected from the vicinity of Olusosun landfill in ojota, Lagos,
Nigeria". Transnational Journal of Science and Technology,3(6): 73-86.

Adegun, O. (2013). "Variation of leachate characteristics from selected dumpsites in Lagos, Nigeria". Journal of Applied Science in Environmental Sanitation, 8(4):249-256.

Aderemi, A.O., Oriaku, A. V., Adewumi, G.A and Otitoloju, A.A. (2011). "Assessment of groundwater contamination by leachate near a municipal solid waste landfill". African Journal of Environmental Science and technology, 5(11): $933-940$.

Adetayo, A.O. (2007)."Impact of waste dump and industrial effluents on groundwater quality at Oluyole industrial Estate, Beere and Bodija estate area of Ibadan metropolis" LAUTECH Journal of Engineering and Technology, 4(2):13 - 18.

Afolayan, O.S ,Ogundele. F.O and Odewumi, S.G (2012). "Spatial Variation in Landfills Leachate Solution in Urbanized Area of Lagos State, Nigeria". American International Journal of Contemporary Research, 2(8):178-184.

Alimba, C. G., Bakare A. A. and Latunji, C. A. (2006). "Municipal landfill leachates induced chromosome aberrations in rat bone marrow cells". African Journal of Biotechnology, 5 (22): 2053-2057.

Al-yagout, A. F. and Hamoda, M. F. (2003). "Evaluation of landfill Leachate in arid elimate-a case study", Environmental International, 29 (5): 593-600. 
American Public Health Association. Standard methods for the examination of water and waste water. Washington, DC,USA; 2005.

Aziz, H. A., Alias, S., Adlan, M. N., Faridahj, A. H. and Zahari, M. S. (2007) "Colour removal from landfill leachate by coagulation and flocculation processes" Bioresource Technology. 98 (1): $218-220$.

Christensen, T. H., Kjeldsen, P. and Kjeldson, P. (2001). "Biogeochemistry of landfill Leachate plumes", Applied Geochemistry, 16 (7-8): 659-718.

Davd, Z., Aziz, H. A. Adlan, M.N. and Hung, Y.T. (2009)."Application of combined filtration and coagulation for semi-aerobic leachate treatment". International Journal of Environmental and Waste Management. 4(3): $457-469$.

Elijah, A.A., Adetayo, F.F. and Olusola, T.K. (2013). "Integrated geophysical and geochemical methods for environmental assessment of municipal dumpsite system" International Journal of Geosciences, 4: 850-862.

Foul, A. A., Aziz, H. A., Isa, M. H. and Hung, Y. T. (2009). "Primary treatment of anaerobic landfill leachate using activated carbon and limestone, batch and column studies". International Journal of Environmental and Waste Management. Vol. 4(3): $232-298$.

Kjelden, P. and Christophersen, $M$. (2001)."Composition of leachate from old landfill in Denmark", Waste management and Research. 19(3):249 - 256.

Kulikowska, D. and Klimiuk, E. (2008). "The effect of landfill age on municipal Leachate composition: review and opportunity." Bioresource Technology. 99 (13): 5891-5985.

Kulikowska, D. and Klimiuk, E. (2008). "The effect of landfill age on municipal leachate composition", Bio-resource Technology, 99 (13): 5981-5985.

Kumar, D. and Alappat, B. J. (2003). "Analysis of Leachate contamination potential of a municipal landfill using Leachate pollution index". Workshop on sustainable landfill management; 147-153.

Kumar, M., Kumari, K., Ramanathan, A. L. and Saxena, R. (2007). "A comparative evaluation of groundwater suitability forirrigation and drinking purposes in two agriculture dominated districts of Punjab, India". Environmental Geology, doi:10.1007/s00254-007-0672-3.

Kurumbein, W. C. and Graybill, F. A. (1965). An introduction to statistical models in geology. New York: McGraw-Hill

Li, X.Z. and Zhao, Q.L.(2002)."Map precipitation from landfill leachate and seawater bittern waste". Environmental Technology, 23(9):989 - 1000.

Longe, E.O. and Balogun, M.R. (2010).

"Groundwaterlquality assessment near a municipal landfill, Lagos, Nigeria". Research Journal of Applied Science, Engineering and Technology.2(1):39-44.
Marttinen, S. K., Kettunen, R. H. and Rintala, J. A. (2003). "Occurrence and removal of organic pollutants in sewages and landfill leachates", Science of the Total Environment, 301 (1): 1-12.

Milke, M.W. and Huitric, R.L. (1993). "Simulating errors in statistical tests of leachate impacted groundwater quality".

Groundwater, 31(4):645 - 654 .

Mohajeri, H. A., Aziz, M. H., Zahad, M. A. and Adlan, M. N. (2010). "Statistical optimisation of process parameters for landfill leachate treatment using electro-fenton techniques". Journal of Hazardous Materials. 176 (3): $749-798$.

Muhammad, U. Hamidi, A. Z. and Mohd, S. Y. (2010). "Variability of parameters involved in Leachate pollution index and determination of LPI from four landfills in Malaysia", International Journal of Chemical Engineering. doi:10.1155/2010/74753.

Ogundiran, O. O., Afolabi, T. A. (2008). "'Assessment of the physicochemical parameters and heavy metals toxicity of leachates from municipal solid waste open dumpsite". International Journal of Environmental Science and Technology, 5 (2): 243-250.

Rajkumar, N., Subramani, T. And Elango L. (2012).' Impact of leachate on groundwater pollution due to non-engineered municipal solid waste landfill sites of erode city, Tamil Nadu, India". Iranian Journal of Environmental Health Science and Engineering, 9(1):35 - 46.

Reinhart, D.R. and Grosh, C.J. (1998). "Analysis of Florida MSW landfill leachate quality". Department of Civil and Environmental Engineering, University of Central Florida.

Renou, S., Givaudan, J. G., Poulain, S., Dirassouyan, F. and Moulin, (2008). "Landfill leachate treatment: Review and opportunity" Journal of Hazardous Materials. 150(3): $468-498$.

Statom, R. A., Thyne, G. D. and McCray, J. E. (2004). "Temporal changes in Leachate chemistry of a municipal solid waste landfill cell in Florida, U.S.A.", Environmental Geology, 45 (7): 982-991.

Suman, M. Khaiwal, R., Dahiya, R.P. and Chandra, A. (2006). "Leachate characterization and assessment of groundwater pollution near municipal solid waste landfill site". Environmental Monitoring Assessment, 8(1-3): 435-56.

Tatsi, A. A. and Zouboulis, A. I. (2002). "A field investigation of the quantity and quality of Leachate from a municipal solid waste landfill in a Mediterranean climate", Advances in Environmental Research, 6 (3): 207-219.

Wijesekara, S.., onia, S.M., Siriwardana, A.R., Nalin, S. Basnayake, B.F.A., Ken, K. and Meththinka, V. (2014)."'Fate and transport of pollutants through a municipal solid waste landfill leachate in Sri Lanka". Environmental Earth Sciences 72 (5), 1707-1719. 
Cite this Article: Salami L. and Susu A.A. (2019). A Comprehensive Study of Leachate Characteristics from Three Soluos Dumpsites in Igando Area of Lagos State, Nigeria. Greener Journal of Environmental Management and Public Safety, 8(1):01-14, http://doi.org/10.15580/GJEMPS.2019.1.110118520. 